\title{
SOCIO-ECONOMIC AND MACRO-FINANCIAL DETERMINANTS AND SPATIAL EFFECTS ON EUROPEAN PRIVATE HEALTH INSURANGE MARKETS
}

\author{
Gabriela Mihaela Mureșan¹, Cristian Mihai Dragoș²*, Codruța Mare ${ }^{3}$,Simona \\ Laura Dragos ${ }^{4}$ and Alexandra Pintea ${ }^{5}$ \\ 1),2),3),4),5) Babeș-Bolyai University, Cluj Napoca, România.
}

\author{
Please cite this article as: \\ Mureșan, G.M., Dragoș, C.M., Mare, C., Dragoș, S.L. \\ and Pintea, A., 2021. Socio-Economic and Macro- \\ Financial Determinants and Spatial Effects on \\ European Private Health Insurance Markets. \\ Amfiteatru Economic, 23(56), pp. 290-307.
}

\section{Article History}

Received: 4 September 2020

Revised: 27 October 2020

Accepted: 26 November 2020

DOI: $10.24818 / \mathrm{EA} / 2021 / 56 / 290$

\begin{abstract}
There is a great variation in the development of private health insurance (PHI) between European countries. Using data provided by Insurance Europe, World Bank and Standard and Poor's for 30 European countries, our research investigates the main factors influencing the size of these markets. In addition to some classical economic and social factors, the role of the size of national macrofinancial aggregates is also highlighted. In order to relax the constraints due to the multicollinearity phenomenon, we use as explanatory variables aggregated indicators, both calculated by financial institutions and by us, based on component items, used as proxy variables for different components of the financial system at national level. Using cross-section regressions with White corrections for heteroskedasticity and elements of spatial econometrics, we also analyze the possible phenomena of clustering and behavioural contagion between the countries in the sample.
\end{abstract}

Keywords: private health insurance, White OLS, spatial econometrics, spatial contagion, clusterization

JEL Classification: G22, C21

* Corresponding author, Cristian Mihai Dragos - e-mail: cristian_dragos@yahoo.com 


\section{Introduction}

The world has a longstanding history of the healthcare industry with insurance coverage. We should all care about our health and pay more attention to the health insurance subject because we are fragile and vulnerable to diseases. As long as we get sick, the demand for private health insurance remains a topical issue. Due to existing regulatory gaps and lack of reform in some European countries, we intend to analyze the influence of different factors on health insurance demand. Moreover, our article refers only to private health insurance (PHI). We feel obliged to emphasize the role of PHI market considering the fact that the European population is facing the phenomenon of ageing.

First, the meaning of health insurance is not univocally accepted, despite of these oftenincurring medical expenses. Even if the cost of health may seem a philosophical issue, it still involves some financial consequences and generates a large proportion of healthcare expenditure relative to GDP over time. According to Eurostat (2017), substantial differences of the level of current healthcare expenditure are still observed (from the highest level in Germany Euro 369 billion equivalent to $11.3 \%$ of GDP to Romania recording the lowest ratio $5.2 \%$ of GDP, equivalent to Euro 9 billion).

Second, starting from the review of the literature we learn an interesting lesson. A large part of the theoretical and empirical evidence is often focused on the determinants of the insurance demand (life/non-life sector), but the influence of drivers on health insurance sector is rather limited at individual level. Pitacco (2014, pp. 29) explains that "health insurance products are usually shared between "life" and "non-life" branches according to national legislation and regulation". Motivated by this gap, our study comes to complete the existing literature and provides an overview of the European health insurance markets using interactive maps.

The remaining of the study is organized as follows: Section 1 presents previous studies of the determinants of the private health insurance market and the hypotheses development; Section 2 describes the data and methodology; Section 3 presents the empirical results and the discussions, and the last section concludes and provides future improvements to the health insurance system.

\subsection{Review of the scientific literature and hypotheses}

\subsection{Review of the scientific literature}

Healthcare systems are categorized, on one hand, as a national health service (NHS), a social insurance system and a private insurance system (Beckfield, Olafsdottir and Sosnaud, 2013) or, on the other as public and private insurance system (Pitacco, 2014, pp. 27). For example, National Health Service is met in the United Kingdom, a social system in Germany and private insurance in almost all countries. A public health insurance is financed through contributions or income-related taxes (see the case of Romania). In opposition, the United States of America have no universal public NHS.

According to Beckfield, Olafsdottir and Sosnaud (2013), the healthcare system can also be classified by organizational configuration and by the role of principal actors. We distinguish the Bismarck model seen in countries such as France, Germany and characterized by a limited role of the state, the Semashko model, where the state directly controls the health sector in countries like Hungary; Bulgaria, Poland or the Czech Republic, and the Beveridge model where the controls are limited (see United Kingdom, Italy, Sweden or Spain). 
Generally, health insurance is defined according to Pitacco (2014, pp. 29) as "a large set of insurance products which provide benefits in the case of need arising from either accident or illness, and leading to loss of income (partial or total, permanent or non-permanent), and/or expenses (hospitalization, medical and surgery expenses, nursery, rehabilitation)". More specifically, European Insurance and Reinsurance Federation (Insurance Europe, 2018) mentions that "private health insurers provide individuals or groups with policies to cover the medical costs of illness or accidents." Even though private insurance is often assimilated to voluntary insurance contracts, there are some exceptions in states such as Germany or The Netherlands where private insurance is mandatory, or in the case of France for example, where all employers have to purchase compulsory health coverage for employees.

The literature concerning the estimation of the insurance demand is extensive. Besides, in the field of PHI, the subject of demand is mainly treated at the individual level. In the macroeconomic estimation of the insurance demand, two indicators of life insurance consumption are frequently used, namely penetration rate (Zerriaa and Noubbigh, 2016; Balcilar, et al., 2020) and density rate (Gaganis, Hasan and Pasiouras, 2020; OlasehindeWilliams and Balcilar, 2020). Balciar, et al. (2020) apply panel techniques for 11 African countries and show that penetration rate has a long-term impact on economic growth. Also, they confirm a bidirectional causality between economic growth and the insurance sector. It has already been substantiated in many studies that the urbanization level is also a key driver of insurance demand (Hwang and Gao, 2003; Curak, et al., 2013). In other words, Liu and Chen (2002) prove that people living in cities are more likely to purchase an insurance agreement compared to those living in rural areas.

$\mathrm{Li}$, et al. (2007) evidenced the positive influence of income, education and financial development levels on life insurance demand in developed economies. Also, the average life expectancy and social security expenditure show an expected negative influence on insurance. Dragos (2014) examines the influence of education and level of urbanization over the insurance demand (life and non-life), employing the methodology of panel data. The article emphasizes that the main development opportunity for non-life insurances in terms of income is emerging Europe. Education and urbanization prove to be significant factors with positive influence for the field of non-life insurance in emerging Europe and Asia, while the Gini index of income distribution has a negative influence for both categories of countries.

In a cross-disciplinary study, Chui and Kwok (2009), analyzed the relationship between life insurance consumption and national culture practice using data from thirty-eight countries. They highlight the role of economic, institutional, cultural and demographic factors in terms of life insurance demand. Moreover, we have identified in the literature studies that have used the human development index (HDI) as a determinant of insurance demand. Thus, the results from the empirical research are disputed: the positive relationship, identified by Truett and Truett (1990) and Browne and Kim (1993) appears to stimulate the insurance demand, but no robust relationship is found in studies conducted by Beck and Webb (2003), and Outreville (1996). Recently, Mare, Dragos and Dragota (2019) evaluated the effects of spatial diffusion and contagion for the 42 Romanian counties. Their empirical results show that local HDI has a significant and positive influence for the Romanian life insurance market. These mixed results may be due to the different types of life insurance included in their databases.

Using a logistic regression model, Lin, Hsiao and Yeh (2017), showed the effects of financial literacy, financial advisors, and information sources on life insurance. All these determinants influence the decision of individuals to buy life insurance contracts. 
As it could be seen in the literature there is empirical evidence that factors such as income, Gini Index, financial development, economic growth, urbanization, financial literacy, human development, and others have an impact on the insurance market.

At the microeconomic level, we identify many articles that study private health insurance in a certain country based on the survey data. In this regard, Bolhaar, Lindeboom and van der Klaauw (2012) show that in the Irish health care system, the asymmetric information is vital to the acceptance of supplementary private health insurance. Nguyen and Knowles (2010) show that the demand for school-age children and adolescent/student health insurance in Vietnam increases significantly with the expected benefits of insurance as measured by proximity to and quality of a tertiary hospital. The findings of Yang (2018) suggest that a key factor that impacts people's enrolment in the voluntary health insurance scheme in rural China is the perception of the quality of care. More recently, Innocenti, et al. (2019) examine if past negative health experiences are positively associated with intentions to purchase insurance for mitigating the risks of income losses due to illnesses and disabilities. Pendzialek, Simic and Stock (2016) review the empirical studies on price elasticity of demand for health insurance.

In a recent review of literature, Śliwiński and Borkowska (2020) divided the determinants of the demand for private voluntary health insurance into the following categories: income and time value, education, age, gender and family size, health status, level of risk aversion and others. However, it is expected that the key factors of health insurance demand are income or health status. At macroeconomic level, it has already been proven (Enz, 2000; Beck and Webb, 2003) the significant and positive influence of income on the insurance demand. At the national level, Propper (1993) in UK, Christiansen, et al. (2002) in Denmark; Barrett and Conlon (2003) in Australia; Machnes (2006) in Israel; Finn and Harmon (2006) in Ireland found the same results. Recently, Tavares (2020) using collected data from the Survey of Health, Aging and Retirement in Europe for 21 countries shows a direct relationship between income and health insurance. The study concludes that younger European men, with higher income, well-educated, married, employed, are more likely to buy a health policy.

Inherent several individual characteristics and socio-economic variables are found to be correlated with the private health insurance demand. In an in-depth analysis of this subject, Kiil (2012) identified 39 papers and concludes that the probability of buying health insurance increases with income and education level. The insurance literature identifies both at the microeconomic level and at the macroeconomic level (Li, et al., 2007; Kjosevski, 2012), a series of common determinants, but also particularities (especially at individual level).

We believe that we all agree with this statement "While people are unable to save their health, they are able to invest in their health" (Lieberthal, 2016, pp. 35). It remains to identify what determines Europeans to purchase private health insurance in a comprehensive study, starting from the assumption that we cannot buy our health, but we can improve the conditions in which we will be treated, investing in a private health policy.

\subsection{Hypotheses}

H1: Health insurance density is positively influenced by the incomes of the inhabitants.

As in the case of any product or service, we expect a direct correlation with incomes. Additionally, especially in the case of low purchasing powers, insurance products are considered as luxury products. That is why we actually expect a non-linear relationship, maybe exponential. 
$H 2$ : Health insurance density is positively influenced by the level of financial development of the country.

Even in the presence of incomes (as control factor), financial development may play a significant role. Despite the rapid economic growth, financial instruments in the former communist countries did not get near the developed European economies. This effect may be due to two major causes. Insurance premiums paid by the insured are invested by the insurance companies on the stock market. If the latter is less significant in a national economy, it may transform in a barrier for the development of the insurance sector, in general, and of the health one in particular. The second cause is determined by the financial education of the citizens. Low levels of this cast down the insurance market development.

H3a: An East-West clusterization direction is to be found for the health insurance sector.

$H 3 b$ : There are significant diffusion and contagion effects.

The former communist countries of the Eastern Europe have had, for a very long time, statecontrolled health systems. Consequently, their citizens were not educated towards a private sector that would require private health insurance contracts. That is why we expect to see a clear clusterization of the sample on the East-West direction, with Eastern countries having much lower health insurance densities. Additionally, as stated in the previous working hypotheses, and following the works of Mare, et al. (2016, 2019a, 2019b) we expect significant contagion or diffusion processes on the health insurance market, conditioned by both the level of human and financial development and the income (internal conditions specific to each country). The contagion and diffusion processes should appear due to the high interdependencies existing among the European countries, that make information travel much faster.

\section{Research methodology}

\subsection{Methodology}

In order to evaluate the three working hypotheses, we have employed, on one hand, the classical OLS regression and, on the other, spatial econometrics tools. Due to the high level of heterogeneity and to treat heteroskedasticity, the OLS regression was constructed in the robust form, with the White correction method applied (White, 1980). The robust estimator obtained (White's estimator or heteroskedasticity-consistent estimator - HCE) is given by the following formula:

$$
v_{H C E}\left(\hat{\beta}_{O L S}\right)=\left(X^{\prime} X\right)^{-1} X^{\prime} \operatorname{diag}\left(\hat{\varepsilon}_{1}^{2}, \ldots, \hat{\varepsilon}_{n}^{2}\right) X\left(X^{\prime} X\right)^{-1}
$$

Hypotheses $\mathrm{Hl}$ and $\mathrm{H} 2$ were tested through this method.

Spatial analysis methods were applied in the last part of the research, to evaluate $H 3$. If significant clusterization processes occur, either on the North-South or the East-West directions, the coefficients of latitude and longitude should be significant in an OLS spatial regression. The sign of the coefficients shows the direction of the increment in the variable (in this case, the health insurance density). The latitude and longitude variables are, actually, the values of the centre means corresponding to the centroids of each spatial unit assessed. But sometimes, the intensity of a phenomenon is much better explained if compared to another. That is why, in order to assess the contagion and diffusion processes stated in $H 3 b$, 
we have constructed the rate maps of the $L N \_D E N S$ over HDI and FIN_DEV. The spatial factor was introduced through the spatial weights matrix used to spatially smoothen the rate maps. This procedure is similar to the robust approach in the classical OLS, being meant to treat the high heterogeneity characteristic to spatial data.

The existence of contagion and diffusion is confirmed if clear spatial arrangements are emphasized by the spatially smoothed rate maps. Another method is to test if there are spatial interactions that should be included in a regression model. The starting point is, again the OLS model, but with the neighboring scheme given by the spatial weights matrix attached. If the spatial diagnostic post-estimation tests (Moran's I for errors and Lagrange Multiplier - LM tests) reject the null hypothesis that the best fitting model is the OLS and they emphasize the need to re-specify the regression with spatial components (spatial autoregressive or spatial moving average), then contagion and diffusion exist. The opposite situation is valid when the OLS regression is accepted.

\subsection{Data and variables}

Data refers to 30 European countries for which information related to health insurance is available, aggregated at national level (Appendix no. 1). Variables to be used in the analysis for the hypotheses testing are synthesized in Table no. 1. They are coded, with explanations and the data source.

Table no. 1. Variables used in the analysis and sources of data

\begin{tabular}{|c|c|}
\hline \multicolumn{2}{|c|}{ Dependent variables } \\
\hline $\begin{array}{l}\text { HLTH_INS_ } \\
\text { DENS }\end{array}$ & $\begin{array}{l}\text { Health Insurance Density (total premiums per inhabitant - domestic } \\
\text { market) is calculated as the ratio of total insurance premiums (in } \\
\text { Euros) to total population. Due to the large positive asymmetry and the } \\
\text { nonlinear correlation with the explanatory variables, in regressions it } \\
\text { will be used in its logarithmic form. } \\
\text { Data from 2018. Source: Insurance Europe }\end{array}$ \\
\hline LN_DENS & The natural logarithm of the variable $H L T H \_I N S \_D E N S$. \\
\hline \multicolumn{2}{|c|}{ Explanatory variables } \\
\hline GDP_CAP & $\begin{array}{l}\text { GDP per capita }\left(10^{3} \text { US } \$\right) \text { is gross domestic product divided by } \\
\text { midyear population. } \\
\text { Data from } 2018 \text {. Source: World Bank. }\end{array}$ \\
\hline GDP_PPP & $\begin{array}{l}\text { GDP by Purchasing Power Parity indicator provides per capita values } \\
\text { for gross domestic product (GDP) expressed in } 10^{3} \text { current } \\
\text { international dollars converted by purchasing power parity (PPP) } \\
\text { conversion factor. } \\
\text { Data from 2018. Source: World Bank. }\end{array}$ \\
\hline GINI_IND & $\begin{array}{l}\text { Gini Index measures the extent to which the distribution of income } \\
\text { among individuals or households within an economy deviates from a } \\
\text { perfectly equal distribution. } \\
\text { Data from 2018. Source: World Bank estimates. }\end{array}$ \\
\hline$U R B A N$ & $\begin{array}{l}\text { Urban population (\% of total) refers to people living in urban areas as } \\
\text { defined by national statistical offices. } \\
\text { Data from } 2018 \text {. Source: World Bank. }\end{array}$ \\
\hline
\end{tabular}

Vol. $23 \cdot$ No. $56 \cdot$ February 2021 


\begin{tabular}{|c|c|}
\hline$L I F E \_E X P$ & $\begin{array}{l}\text { Life Expectancy at birth indicates the number of years a newborn } \\
\text { infant would live if prevailing patterns of mortality at the time of its } \\
\text { birth were to stay the same throughout its life. Data from } 2018 \text {. Source: } \\
\text { World Bank. }\end{array}$ \\
\hline HDI & $\begin{array}{l}\text { The Human Development Index (HDI) is a summary measure of } \\
\text { average achievement in key dimensions of human development: a long } \\
\text { and healthy life, being knowledgeable and have a decent standard of } \\
\text { living. The HDI is the geometric mean of normalized indices for each } \\
\text { of the three dimensions. Data from 2018. Source: United Nations } \\
\text { Development Programme - Human Development Reports. }\end{array}$ \\
\hline MK_CAP & $\begin{array}{l}\text { Market capitalization of listed domestic companies (\% of GDP) is the } \\
\text { share price times the number of shares outstanding (including their } \\
\text { several classes) for listed domestic companies. Due to the large } \\
\text { fluctuations of prices on the capital market and the lack of data for a } \\
\text { certain year or country in the sample, the maximum value from the } \\
\text { time interval } 2014 \text { - } 2018 \text { was considered. Source: World Bank. }\end{array}$ \\
\hline$P R V_{-} C R D$ & $\begin{array}{l}\text { Domestic credit to private sector (\% of GDP) refers to financial } \\
\text { resources provided to the private sector by financial corporations, such } \\
\text { as through loans, purchases of nonequity securities, and trade credits } \\
\text { and other accounts receivable, that establish a claim for repayment. } \\
\text { Data from 2018. Source: World Bank. }\end{array}$ \\
\hline$F I N \_L I T$ & $\begin{array}{l}\text { Financial Literacy Index survey probes four basic financial concepts: } \\
\text { risk diversification, inflation, numeracy, and compound interest. Based } \\
\text { on interviews with more than } 150,000 \text { adults across } 148 \text { countries, the } \\
\text { survey gives researchers, policy makers, and practitioners a unique, } \\
\text { first-of-its kind, and in-depth look at financial literacy across the globe. } \\
\text { Data from 2018. Source: Standard \& Poor's. }\end{array}$ \\
\hline$F I N \_D E V$ & $\begin{array}{l}\text { Financial Development is a composite index based on the variables } \\
M K \_C A P, P R V \_C R D \text { and } F I N \_L I T \text {. Calibrated for possible values } \\
\text { from } 0 \text { to } 100 \text {. High values of the index are due to high values of the } \\
\text { credit market, the capital market and the good financial education of } \\
\text { the population. } \\
\text { Source: authors' calculation. }\end{array}$ \\
\hline
\end{tabular}

Source: World Bank, Insurance Europe, Standard \& Poor's, United Nations Development Programme and authors' calculation.

\subsection{Construction of the FIN_DEV composite index}

FIN_DEV is defined based on the MK_CAP, PRV_CRD and FIN_LIT variables. These have different measurement units and scales. In order to aggregate them, we have, first, standardized them. Let:

$$
\begin{aligned}
& I_{1}=\text { MK_CAP } \\
& I_{2}=P R V \_C R D \\
& I_{3}=F I N \_L I T
\end{aligned}
$$


Using the index $i=1, \ldots, \mathrm{N}$ for the countries in the sample and $I_{j}, j=1,2,3$ the three indicators. A normalized value, centered and reduced, can be computed for each indicator and country, through the classical standardization procedure (subtracting the average and dividing by the standard deviation).

$$
X_{j i}=\operatorname{normI}_{j i}=\left(I_{j i}-\bar{I}_{j}\right) / \sigma_{I_{j}}
$$

the normalized value for indicator $I_{j}$ for the $i$ country.

In order to obtain values from 0 to 100 for each indicator, we use the normal distribution (Gauss) upon the standardized value of each indicator.

$$
F I N_{-} D E V_{i}=\frac{c_{1}\left(100 \int_{-\infty}^{X_{t_{i}}} \frac{1}{\sqrt{2 \pi}} e^{-t^{2} / 2} d t\right)+c_{2}\left(100 \int_{-\infty}^{X_{2 i}} \frac{1}{\sqrt{2 \pi}} e^{-t^{2} / 2} d t\right)+c_{3}\left(100 \int_{-\infty}^{X_{3 i}} \frac{1}{\sqrt{2 \pi}} e^{-t^{2} / 2} d t\right)}{c_{1}+c_{2}+c_{3}}
$$

Where $c_{1}, c_{2}$ and $c_{3}$ represent shares $(\%)$ of the $I_{1}, I_{2}$ and $I_{3}$ indicators that can be changes under the restriction: $c_{1}+c_{2}+c_{3}=1(100 \%)$. In our application, we have maintained equal shares $\left(c_{1}=c_{2}=c_{3}\right)$ for MK_CAP, PRV_CRD and FIN_LIT.

To verify the robustness of the aggregation of a composite index based on its component items, we use Cronbach's alpha (tau-equivalent reliability).

$$
\rho_{T}=\frac{k}{k-1}\left(1-\frac{\sum_{i=1}^{k} \sigma_{i}^{2}}{\sigma_{X}^{2}}\right)
$$

$X_{i}$ denotes the observed score for item $i$, while $X=\left(X_{1}+X_{2}+\ldots X_{i}+\ldots+X_{k}\right)$ is the composite index (variable) index formed by the $k$ items $X_{1}, X_{2}, \ldots X_{i} \ldots X_{k} . \sigma_{i}$ denotes the standard deviation of $X_{i}$ and $\sigma_{X}$ denotes the standard deviation of $X$.

\section{Results and discussion}

The distribution of the health insurance density values for the countries in the sample points out a very high variation, from $0.86 € /$ habitant in Hungary to $2719 €$ /habitant in the Netherlands.

Figure 1 shows the country distribution of the HLTH_INS_DENS variable, both on the linear and logarithmic scales. We do this in order to be able to also observe the differences existing between countries with low values.

Evaluating the descriptive statistics of the variables we observe that the relative variation of the health insurance density (2.213) is much higher than that of the income proxy variables (GDP_CAP and GDP_PPP) (Table 2). This suggests that the development of the health insurance sector is not strictly linked to the population's purchasing power, but also to other factors (like, for example, the financial development of a country). 


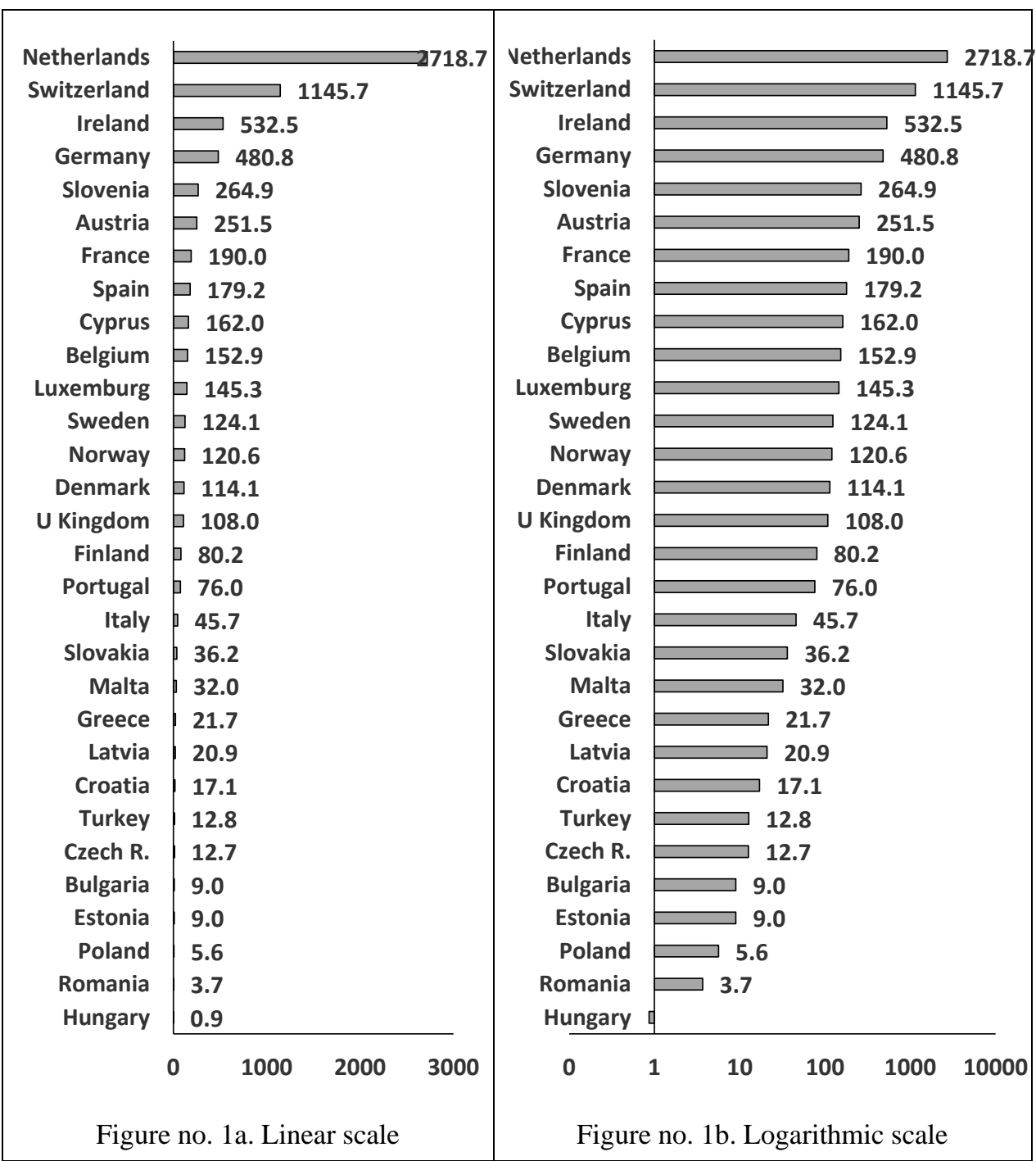

Figure no. 1. Health insurance density distribution for the countries in the sample

Source: authors' calculation in Excel, using data from Insurance Europe (2018)

Table no. 2. Descriptive statistics

\begin{tabular}{|l|r|r|r|r|r|}
\hline & Min & Max & Mean & St Dev & Coef Var \\
\hline HLTH_INS_DENS & 0.865 & 2719 & 235.8 & 521.8 & 2.213 \\
\hline GDP_CAP & 9.370 & 116.65 & 38.833 & 25.74 & 0.663 \\
\hline GDP_PPP & 22.60 & 116.79 & 46.490 & 19.47 & 0.419 \\
\hline GINI_IND & 24.2 & 41.4 & 31.5 & 4.19 & 0.133 \\
\hline URBAN & 53.7 & 98 & 74.5 & 11.6 & 0.156 \\
\hline
\end{tabular}




\begin{tabular}{|c|c|c|c|c|c|}
\hline & Min & Max & Mean & St Dev & Coef Var \\
\hline LIFE_EXP & 74.8 & 83.8 & 80.3 & 2.69 & 0.034 \\
\hline HDI & 0.806 & 0.954 & 0.890 & 0.042 & 0.047 \\
\hline MK_CAP & 8.3 & 160.9 & 58.1 & 38.0 & 0.655 \\
\hline$P R V \_C R D$ & 25.7 & 139.6 & 78.5 & 28.5 & 0.363 \\
\hline$F I N \_L I T$ & 22 & 71 & 50.3 & 13.606 & 0.270 \\
\hline$F I N \_D E V$ & 4.9 & 89.6 & 49.2 & 23.9 & 0.486 \\
\hline
\end{tabular}

Additionally, one can see that the distribution of the health insurance density has a significant positive skewness (Figure no. 2). Consequently, we will use the log of the variable in the regression models, $L N \_D E N S$. In this way, the shape of the distribution gets closer to the normal one (Figure no. 3).

Moreover, skewness reduction also relaxes the heteroskedasticity problem. After taking the $\log$, the distribution is quasi-symmetrical and gets closer to a normal one (Figure no. 3).

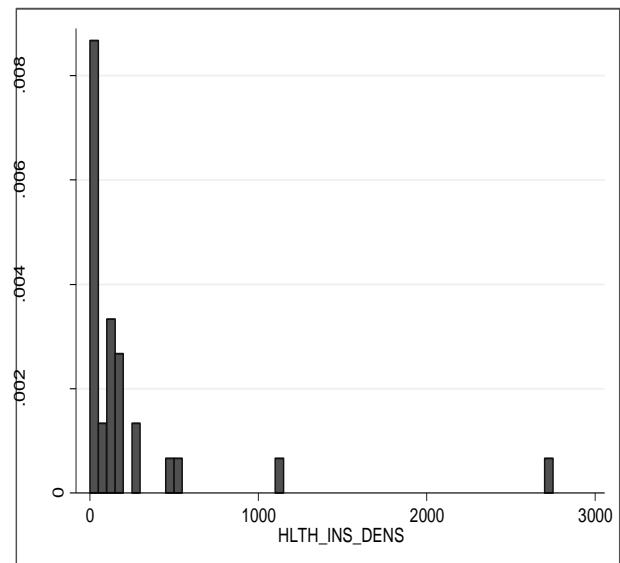

Figure no. 2. Asymmetrical distribution of the $H L T H \_I N S \_D E N S$ variable

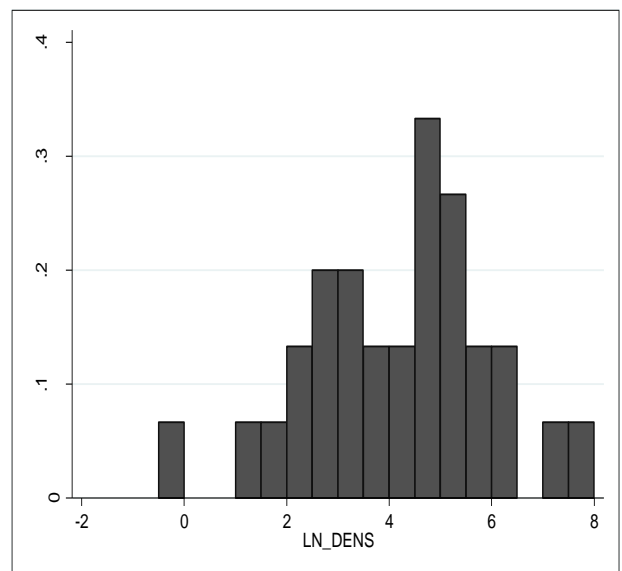

Figure no. 3. Distribution of the $L N \_D E N S$ variable

In the single factor regressions (Table no. 3, OLS 1-8), almost all variables are significant (with the exception of the GINI_IND) and with the expected sign.

But in the multiple regressions (Table no. 4, OLS 9-10) some of the coefficients lose their significance. This is due to the strong correlations existing between the exogenous variables (Table no. 5).

In order to overcome this inconvenient and be able to demonstrate the influence of both the purchasing power and the financial development upon the health insurance density, we employ composite indexes (variables). For a country's standard of living there is such an index - HDI - the Human Development Index.

Among other factors, this includes the GDP/cap and the Life Expectancy - which are also considered in our study. But for the financial development of a country we had to construct an aggregated index, FIN_DEV, which contains the variables related to the credit and stock markets and to the financial education of population. The index is representative for its 
components $($ Cronbach alpha $=0.761)$. The technical aspects related to the construction of FIN_DEV are to be found in the Methodology. The possible theoretical values of the indicator range from 0 to 100 , with high values standing for a good financial development of the country. In our sample of 30 European countries, the lowest value was obtained for Romania (4.9), while the highest for the Netherlands (89.6). The country distribution of this indicator is to be found in Appendix no. 2.

Table no. 3. Results of the simple OLS regressions: dependent variable $L N \_D E N S$, coefficients and $t$-stat

\begin{tabular}{|c|c|c|c|c|c|c|c|c|}
\hline & $\begin{array}{c}\text { OLS } \\
\text { (1) }\end{array}$ & $\begin{array}{c}\text { OLS } \\
(2)\end{array}$ & $\begin{array}{c}\text { OLS } \\
\text { (3) }\end{array}$ & $\begin{array}{c}\text { OLS } \\
\text { (4) }\end{array}$ & $\begin{array}{c}\text { OLS } \\
(5)\end{array}$ & $\begin{array}{c}\text { OLS } \\
(6)\end{array}$ & $\begin{array}{c}\text { OLS } \\
(7)\end{array}$ & $\begin{array}{c}\text { OLS } \\
(8)\end{array}$ \\
\hline GDP_CAP & $\begin{array}{c}* * * 0.05 \\
(4.65)\end{array}$ & . & . & . & . & . & . & . \\
\hline$G D P \_P P P$ &. & $\begin{array}{c}* * * 0.06 \\
(4.02)\end{array}$ & . & . & . & . & . & . \\
\hline GINI_IND & . & & $\begin{array}{c}0.02 \\
(1.25)\end{array}$ & & . & . & . & . \\
\hline URBAN & . & . & . & $\begin{array}{l}* 0.04 \\
(1.72)\end{array}$ & . & . & . & . \\
\hline LIFE_EXP & . & . & . & . & $\begin{array}{c}* * * 0.49 \\
(6.10)\end{array}$ & . & . & . \\
\hline MK_CAP & . & . & . & . & . & $\begin{array}{c}* * * 0.03 \\
(5.47)\end{array}$ & . & . \\
\hline$P R V_{-} C R D$ & . & . & . & & . & . & $\begin{array}{c}* * * 0.04 \\
(4.16)\end{array}$ & . \\
\hline$F I N \_L I T$ & . & . & . & & . & . & . & $\begin{array}{c}* * 0.06 \\
(2.69)\end{array}$ \\
\hline constant & $\begin{array}{c}* * * 2.36 \\
(5.21)\end{array}$ & $\begin{array}{c}* * 1.56 \\
(2.27) \\
\end{array}$ & $\begin{array}{r}* * 7.00 \\
(2.82) \\
\end{array}$ & $\begin{array}{c}0.90 \\
(0.47) \\
\end{array}$ & $\begin{array}{c}* * *-35.9 \\
(-5.47)\end{array}$ & $\begin{array}{c}* * * 2.18 \\
(5.15)\end{array}$ & $\begin{array}{c}0.98 \\
(1.31) \\
\end{array}$ & $\begin{array}{c}1.15 \\
(1.01) \\
\end{array}$ \\
\hline $\mathbf{R}^{2}$ & 0.436 & 0.366 & 0.046 & 0.095 & 0.571 & 0.516 & 0.415 & 0.206 \\
\hline
\end{tabular}

Note: $* * * * *, *:$ significant at $1 \%, 5 \%$ and $10 \%$ level.

Source: authors' calculation in STATA.

The two composite indexes, $H D I$ and $F I N \_D E V$ are both statistically significant, regardless if they are used as single factors or together, in the same regression (Table no. 4, OLS 1113). These results validate hypotheses $H 1$ and $H 2$.

Table no. 4. Results of the multifactorial OLS regressions and the composite indexes regressions: dependent variable $L N \_D E N S$, coefficients and $t$-stat

\begin{tabular}{|c|c|c|c|c|c|}
\hline & OLS (9) & OLS (10) & OLS (11) & OLS (12) & OLS (13) \\
\hline GDP_CAP & 0.009 & $\cdot$ & $\cdot$ & & $\cdot$ \\
& $(0.73)$ & & & & \\
\hline GDP_PPP & $\cdot$ & 0.013 & $\cdot$ & & $\cdot$ \\
& & $(0.93)$ & & & \\
\hline GINI_IND & -0.002 & -0.003 & $\cdot$ & & $\cdot$ \\
& $(-0.03)$ & $(-0.05)$ & & & \\
\hline URBAN & $*-0.039$ & $*-0.040$ & $\cdot$ & & $\cdot$ \\
& $(-1.88)$ & $(-1.93)$ & & & \\
\hline
\end{tabular}




\begin{tabular}{|c|c|c|c|c|c|}
\hline & OLS (9) & OLS (10) & OLS (11) & OLS (12) & OLS (13) \\
\hline$L I F E \_E X P$ & $\begin{array}{c}* * 0.270 \\
(2.25)\end{array}$ & $\begin{array}{c}* * 0.263 \\
(2.24)\end{array}$ & . & . & \\
\hline MK_CAP & $\begin{array}{c}* * 0.0178 \\
(2.22)\end{array}$ & $\begin{array}{c}* * 0.018 \\
(2.25)\end{array}$ & . & . & . \\
\hline$P R V_{-} C R D$ & $\begin{array}{l}0.008 \\
(0.81)\end{array}$ & $\begin{array}{l}0.009 \\
(0.90)\end{array}$ & . & . & . \\
\hline$F I N \_L I T$ & $\begin{array}{l}0.020 \\
(0.85)\end{array}$ & $\begin{array}{l}.0 .021 \\
(0.94)\end{array}$ & . & . & . \\
\hline$H D I$ & . & . & $\begin{array}{c}* * * 32.44 \\
(6.15)\end{array}$ & . & $\begin{array}{c}* * 19.67 \\
(2.51)\end{array}$ \\
\hline$F I N \_D E V$ & . & . & . & $\begin{array}{c}* * * 0.055 \\
(5.84)\end{array}$ & $\begin{array}{c}* * 0.029 \\
(2.12)\end{array}$ \\
\hline constant & $\begin{array}{c}*-17.60 \\
(-1.76)\end{array}$ & $\begin{array}{c}*-17.36 \\
(-1.80)\end{array}$ & $\begin{array}{c}* * *-24.73 \\
(-5.26)\end{array}$ & $\begin{array}{c}* * * 1.425 \\
(2.78)\end{array}$ & $\begin{array}{c}* *_{-}-14.78 \\
(-2.29)\end{array}$ \\
\hline $\mathbf{R}^{2}$ & 0.739 & 0.743 & 0.575 & 0.550 & 0.635 \\
\hline
\end{tabular}

Note: $* * * * *, *:$ significant at $1 \%, 5 \%$ and $10 \%$ level.

Source: authors' calculation in STATA.

Table no. 5. The Pearson correlation coefficients between variables

\begin{tabular}{|l|r|r|r|r|r|r|r|r|r|}
\hline & $(\mathbf{1})$ & $\mathbf{( 2 )}$ & $\mathbf{( 3 )}$ & $\mathbf{( 4 )}$ & $\mathbf{( 5 )}$ & $\mathbf{( 6 )}$ & (7) & (8) & (9) \\
\hline LN_DENS (1) & 1.000 & & & & & & & & \\
\hline GDP_CAP (2) & 0.660 & 1.000 & & & & & & & \\
\hline GDP_PPP (3) & 0.605 & 0.971 & 1.000 & & & & & & \\
\hline GINI_IND (4) & -0.215 & -0.159 & -0.121 & 1.000 & & & & & \\
\hline URBAN (5) & 0.309 & 0.448 & 0.400 & -0.017 & 1.000 & & & & \\
\hline LIFE_EXP (6) & 0.756 & 0.656 & 0.594 & -0.254 & 0.464 & 1.000 & & & \\
\hline MK_CAP (7) & 0.718 & 0.607 & 0.531 & -0.024 & 0.530 & 0.623 & 1.000 & & \\
\hline PRV_CRD (8) & 0.644 & 0.486 & 0.389 & 0.001 & 0.451 & 0.655 & 0.682 & 1.000 & \\
\hline FIN_LIT (9) & 0.454 & 0.591 & 0.500 & -0.525 & 0.508 & 0.421 & 0.394 & 0.296 & 1.000 \\
\hline
\end{tabular}

Source: authors' calculation in STATA.

The present sample consists in European countries, that/which are linked through significant socio-economic relationships. This intense interdependence must be taken into account, as clusterization or contagion effects may appear. In order to treat this, we have included space as an analysis dimension. By doing this, we have also accounted for the neighbouring effect in the analyzed sample. Results obtained through the classical procedures (Tables no. 3 and 4), show the positive relationship existing between the level of development and the health insurance market. 


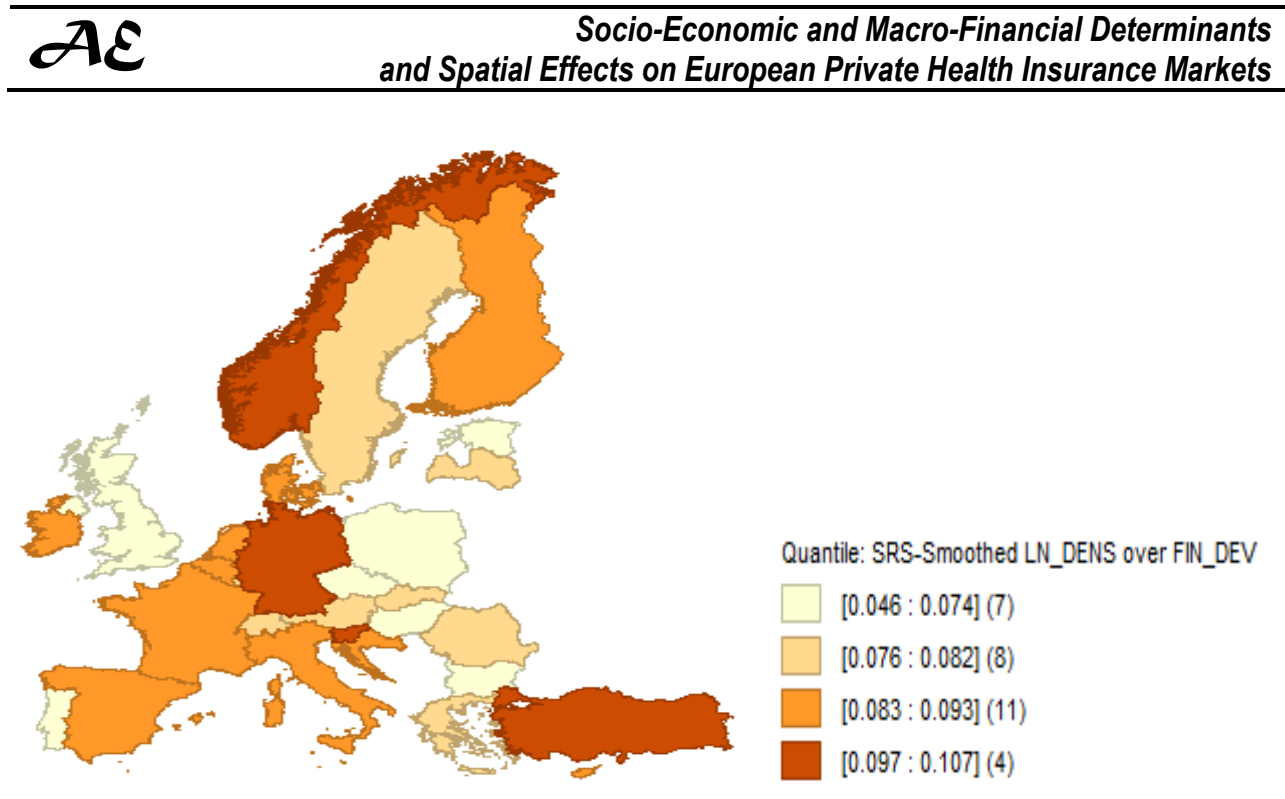

Figure no. 4. Quartile map $L N \_D E N S$ over $F I N \_D E V$

Source: authors' calculation in GeoDa.
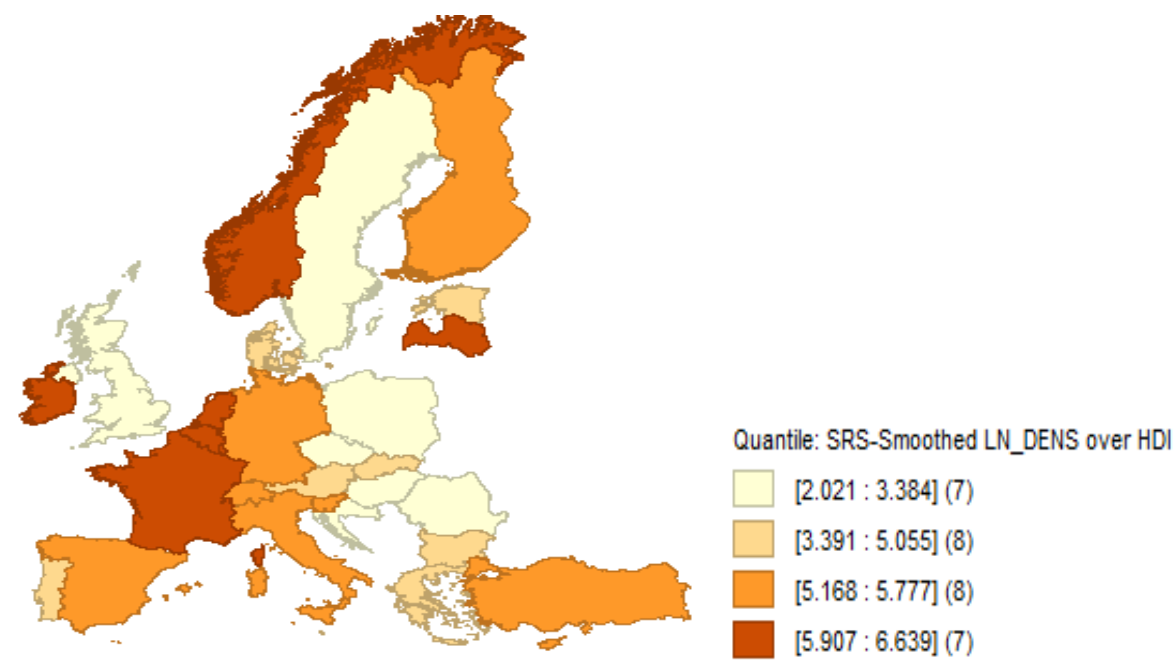

Figure no. 5. Quartile map $L N \_D E N S$ over $H D I$

Source: authors' calculation in GeoDa.

As the former is characterized by a significant East-West clusterization in Europe, we also expect this to be valid for the development of the health insurance sector. Former communist countries, in which the health sector is strongly sustained by the state, have a lower development level of this type of insurance products. To test this, we have employed the simple spatial regression with latitude and longitude as independents. Only the coefficient of longitude turned out to be significant ( $p$-value $=0.002<0.05$ ) and negative, proving that as we go from West to East, the health insurance density lowers (Table no. 6). For the 
assessment of the contagion and diffusion processes, we have first constructed the rate maps of $L N \_D E N S$ over FIN_DEV and HDI. But due to the high heterogeneity level, these maps were constructed in the spatially smoothed form (Figures no. 4 and 5).

According to Mare et al. (2019a, 2019b), if a significant diffusion and contagion process is to be found, a clear grouping direction should be present on these maps. None of the two figures have this feature. The lack of a diffusion and contagion process is finally confirmed by the regression analysis, as the classical OLS model is not rejected by any of the spatial diagnostics tests (Table no. 6 - all spatial diagnostic tests have probabilities $>0.05$ ). Consequently, we partially accept $H 3$ - there is a significant clusterization based on longitude $(H 3 a)$, but no significant contagion and diffusion processes ( $H 3 b$ rejected).

Table no. 6. Spatial regression results; dependent variable $L N \_D E N S$; coefficients and $t$-stat

\begin{tabular}{|c|c|c|c|c|}
\hline & OLS (14) & OLS (15) & OLS (16) & OLS (17) \\
\hline Latitude & $0.1 \mathrm{e}-6(0.2 \mathrm{e}-6)$ & - & - & - \\
\hline Longitude & $* * *-0.8 \mathrm{e}-5(0.2 \mathrm{e}-5)$ & - & - & - \\
\hline$H D I$ & - & $* * * 32.436(5.27)$ & - & $* * 19.669(7.82)$ \\
\hline$F I N \_D E V$ & - & - & $* * * 0.055(0.009)$ & $* * 0.029(0.014)$ \\
\hline constant & $* * * 4.269(1.31)$ & $* * *-24.73(4.7)$ & ****1.43(0.51) & $* *_{-14.77}(6.46)$ \\
\hline $\mathbf{R}^{2}$ & 0.313 & 0.575 & 0.55 & 0.635 \\
\hline \multicolumn{5}{|c|}{ Spatial diagnostic test (probs) } \\
\hline Moran's I error & - & 0.107 & 0.134 & 0.162 \\
\hline LM lag & - & 0.223 & 0.101 & 0.122 \\
\hline Robust LM lag & - & 0.689 & 0.279 & 0.298 \\
\hline LM error & - & 0.187 & 0.217 & 0.247 \\
\hline Robust LM er. & - & 0.519 & 0.991 & 0.876 \\
\hline LM SARMA & & 0.387 & 0.261 & 0.298 \\
\hline
\end{tabular}

Note: $* * * * *, *$ : significant at $1 \%, 5 \%$ and $10 \%$ level.

Source: authors' calculation in GeoDa.

\section{Conclusion}

For a sample of 30 European countries, we have assessed the macroeconomic factors that determine the development of the private health insurance sector. As expected, there is a high heterogeneity in terms of health insurance density in the analyzed sample. These high discrepancies are due to the past of each society and the level of socio-economic development. And there is an important link between the two. The Western group of countries was democratic after the $2^{\text {nd }}$ World War, thing that led to a certain type of development and social education. It is very well known that there is a significant clusterization process in Europe, with Western states having a much higher purchasing power and standard of living.

Our first set of results clearly shows a positive relationship between the GDP (measured in any form) and the health insurance density. This can be explained by the fact that the private health insurance sector was able to develop in countries where the economic environment allowed for private intervention in the economy, that brought, especially in the health sector, a much higher quality than the public one. Additionally, this cluster of countries also has the most developed financial markets and a high level of financial literacy of the citizens. This, 
again, brings into light another important specificity - the health insurance contract, in respect to other such products, is seen as a luxury product, so a high standard of living is necessary for a person to buy such a contract. On the contrary, the Eastern, ex-communist states, have a long history of publicly sustained sectors, with a very important gap in the economic and financial education of their inhabitants. In these socialist nations, the inhabitant was used to be provided with all the social security issues by the state.

A second very important result is the demonstration that, in Europe, both the level of human development and the financial one, significantly and positively influence the private health insurance sector. These results emphasize the transmission channels on which actors in this domain should interfere in order to increase the demand for such products. A last group of results may be divided into two. On one hand, the spatial analysis conducted has clearly shown that the positive relationship between the level of development and the health insurance sector has materialized in a similar clusterization direction in Europe based on the latter - East-West, with Eastern countries having much lower levels. On the other, an important assumption was not validated. Previous studies in the field of insurance have demonstrated contagion and diffusion processes existing for different types of insurance products. As there is a very high interaction in Europe, due to the European Union and all the socio-economic agreements, we have also expected such contagion and diffusion to be present for the private health insurance market. This, because information travels fast, there is very high mobility of people, goods and capital, etc. On the contrary, the present analysis has emphasized the lack of spatial contagion and diffusion processes. This is a very important result, as this means that the private health insurance sector, in comparison with other types of insurance, is more influenced by the internal, domestic conditions specific to each country. And this impact is that high, that it cancels the transmission channels and the information coming from outside a certain nation.

An important implication arises from the analysis - actors interested in developing the private health insurance market should address the internal specificities of each national market and create products according to the country's financial and social development.

\section{Funding}

This work was supported by a grant of the Romanian Ministry of Education and Research, CNCS - UEFISCDI, project number PN-III-P1-1.1-TE-2019-0554, within PNCDI III.

\section{References}

Balcilar, M., Gupta, R., Lee, C.C. and Olasehinde-Williams, G., 2020. Insurance-growth nexus in Africa. The Geneva Papers on Risk and Insurance-Issues and Practice, 45(2), pp.335-360. DOI: 10.1057/s41288-019-00145-7.

Beck, T. and Webb, I., 2003. Economic, demographic, and institutional determinants of life insurance consumption across countries. The World Bank Economic Review, 17(1), pp.51-88.

Beckfield, J., Olafsdottir, S. and Sosnaud, B., 2013. Healthcare systems in comparative perspective: classification, convergence, institutions, inequalities, and five missed turns. Annual review of sociology, 39(1), pp.127-146. 
Boes, S. and Gerfin, M., 2016. Does full insurance increase the demand for health care? Health economics, 25(11), pp.1483-1496.

Bolhaar, J., Lindeboom, M. and Van Der Klaauw, B., 2012. A dynamic analysis of the demand for health insurance and health care. European Economic Review, 56(4), pp.669-690.

Browne, M.J. and Kim, K., 1993. An international analysis of life insurance demand. Journal of Risk and Insurance, 60(4), pp.616-634.

Cantarero-Prieto, D., Pascual-Sáez, M. and Gonzalez-Prieto, N., 2017. Effect of having private health insurance on the use of health care services: the case of Spain. BMC health services research, 17(1), pp.716.

Chang, C.H. and Lee, C. C., 2012. Non-linearity between life insurance and economic development: A revisited approach. The Geneva Risk and Insurance Review, 37(2), pp. 223-257.

Christiansen, T., Lauridsen, J. and Kamper-Jørgensen, F., 2002. Demand for private health insurance and demand for health care by privately and non-privately insured in Denmark. Syddansk Universitet.

Chui, A.C. and Kwok, C.C., 2009. Cultural practices and life insurance consumption: An international analysis using GLOBE scores. Journal of Multinational Financial Management, 19(4), pp. 273-290.

Curak, M., Dzaja, I. and Pepur, S., 2013. The effect of social and demographic factors on life insurance demand in Croatia. International Journal of Business and Social Science, 4(9), pp. 65-72.

Dragos, S.L., 2014. Life and non-life insurance demand: the different effects of influence factors in emerging countries from Europe and Asia. Economic research-Ekonomska istraživanja, 27(1), pp. 169-180.

Elango, B. and Jones, J., 2011. Drivers of insurance demand in emerging markets. Journal of Service Science Research, 3(2), pp. 185-204.

Enz, R., 2000. The S-curve relation between per-capita income and insurance penetration. The Geneva Papers on Risk and Insurance-Issues and Practice, 25(3), pp. 396-406.

Finn, C. and Harmon, C.P., 2006. A dynamic model of demand for private health insurance in Ireland. Discussion Papers Series IZA DP No. 2472, pp. 1-38.

Gaganis, C., Hasan, I. and Pasiouras, F., 2020. Cross-country evidence on the relationship between regulations and the development of the life insurance sector. Economic Modelling, 89(July), pp. 256-272.

Hwang, T. and Gao, S., 2003. The determinants of the demand for life insurance in an emerging economy - The case of China. Journal of Managerial Finance, 29(5/6), pp. 82-96.

Innocenti, S., Clark, G. L., McGill, S. and Cuñado, J., 2019. The effect of past health events on intentions to purchase insurance: evidence from 11 countries. Journal of Economic Psychology, 74(Oct), pp. 1-21.

Insurance Europe, 2015. Statistics: European insurance industry database. Density (total premiums per inhabitant): domestic market. [pdf] Insurance Europe. $<$ https://www.insuranceeurope.eu/sites/default/files/attachments/European\%20Insurance $\% 20-\% 20$ Key\%20Facts\%20-\%20August\%202015.pdf> [Accessed 20 September 2020].

Insurance Europe, 2018. European Insurance in Figures, 2018 data. [pdf] Insurance Europe. Available at: <https://www.insuranceeurope.eu/sites/default/files/attachments/European $\% 20$ Insurance $\% 20$ in \%20Figures\%20-\%202018\%20data.pdf $>$ [Accessed 20 September 2020]. 
Kiil, A., 2012. What characterizes the privately insured in universal health care systems? A review of the empirical evidence. Health Policy, 106(1), pp. 60-75.

Kjosevski, J., 2012. The determinants of life insurance demand in central and southeastern Europe. International Journal of Economics and Finance, 4(3), pp. 237-247.

Li, D., Moshirian, F., Nguyen, P. and Wee, T., 2007. The demand for life insurance in OECD countries. Journal of Risk and Insurance, 74(3), pp. 637-652.

Lieberthal, R.D., 2016. What Is Health Insurance (Good) For?: An Examination of Who Gets It, Who Pays for It, and How to Improve It. Springer International Publishing.

Lin, C., Hsiao, Y.J. and Yeh, C.Y., 2017. Financial literacy, financial advisors, and information sources on demand for life insurance. Pacific-Basin Finance Journal, 43(June), pp. 218-237.

Liu, T.C. and Chen, C.S., 2002. An analysis of private health insurance purchasing decisions with national health insurance in Taiwan. Social science and medicine, 55(5), pp. 755-774.

Machnes, Y., 2006. The demand for private health care under national health insurance. The European Journal of Health Economics, 7(4), pp. 265-269.

Mare, C., Dragos, S.L., Dragota, I.M., Muresan, G.M. and Urean, C.A., 2016. Spatial convergence processes on the European Union's life insurance market. Economic Computation and Economic Cybernetics Studies and Research, 50(4), pp. 93-107.

Mare, C., Dragoș, S.L., Dragotă, I.M. and Dragoș, C.M., 2019a. Insurance Literacy and Spatial Diffusion in the Life Insurance Market: A Subnational Approach in Romania. Eastern European Economics, 57(5), pp. 375-396.

Mare, C., Dragoș, S.L. and Dragotă, I.M., 2019b. The impact of human development on the Romanian life insurance market: A county spatial econometric analysis. Cogent Business and Management, 6(1), pp. 1-15.

Nguyen, H. and Knowles, J., 2010. Demand for voluntary health insurance in developing countries: the case of Vietnam's school-age children and adolescent student health insurance program. Social Science and Medicine, 71(12), pp. 2074-2082.

Olasehinde-Williams, G. and Balcilar, M., 2020. Examining the Effect of Globalization on Insurance Activities in Large Emerging Market Economies. Research in International Business and Finance, 53(1), pp. 1-15

Outreville, J.F., 1996. Life insurance markets in developing countries. Journal of risk and insurance, 63(2), pp. 263-278.

Pendzialek, J.B., Simic, D. and Stock, S., 2016. Differences in price elasticities of demand for health insurance: a systematic review. The European Journal of Health Economics, 17(1), pp. 5-21.

Pitacco, E., 2014. Health Insurance Products. Basic Actuarial Models. Springer International Publishing.

Propper, C., 1993. Constrained choice sets in the UK demand for private medical insurance. Journal of Public Economics, 51(3), pp. 287-307.

Śliwiński, A. and Borkowska, I., 2020. Private Voluntary Health Insurance: Market in Poland and Determinants of Demand - Review of Literature. In: M. Janowicz-Lomott, K. Łyskawa, P. Polychronidou and A. Karasavvoglou, eds. Economic and Financial Challenges for Balkan and Eastern European Countries. [online] Cham: Springer International Publishing. pp.177-192. Available at: <http://link.springer.com/10.1007/ 978-3-030-39927-6_11> [Accessed 4 September 2020].

Standard \& Poor's, 2018. S\&P Global Financial Literacy Survey: Financial Literacy Around the World - GFLEC. [online] Standard \& Poor's. Available at: <https://gflec.org/wp- 
content/uploads/2015/11/3313-Finlit_Report_FINAL-5.11.16.pdf?x93521> [Accessed 11 September 2020].

Tavares, A.I., 2020. Voluntary private health insurance demand determinants and risk preferences: Evidence from SHARE. The International Journal of Health Planning and Management, 35(3), pp. 685-703.

Trinh, T., Nguyen, X. and Sgro, P., 2016. Determinants of non-life insurance expenditure in developed and developing countries: an empirical investigation. Applied Economics, 48(58), pp. 5639-5653.

Truett, D.B. and Truett, L.J., 1990. The demand for life insurance in Mexico and the United States: A comparative study. Journal of Risk and Insurance, 57(2), pp. 321-328.

White, H., 1980. A heteroskedasticity-consistent covariance matrix estimator and a direct test for heteroskedasticity. Econometrica, 48(4), pp. 817-838.

World Bank, 2018. Indicators: Economy \& Growth, Financial Sector, Gender, Health. Washington, DC: World Bank.

Yang, M., 2018. Demand for social health insurance: evidence from the Chinese new rural cooperative medical scheme. China Economic Review, 52, pp. 126-135.

Zerriaa, M. and Noubbigh, H., 2016. Determinants of life insurance demand in the MENA region. The Geneva Papers on Risk and Insurance-Issues and Practice, 41(3), pp. 491-511.

\section{Appendix no. 1. List of European countries in the sample}

Austria (AT), Belgium (BE), Bulgaria (BG), Croatia (HR), Cyprus (CY), Czech Republic (CZ), Denmark (DK), Estonia (EE), Finland (FI), France (FR), Germany (DE), Greece (GR), Hungary (HU), Ireland (IE), Italy (IT), Latvia (LV), Luxemburg (LU), Malta (MT), Netherlands (NL), Norway (NO), Poland (PL), Portugal (PT), Romania (RO), Slovakia (SK), Slovenia (SI), Spain (ES), Sweden (SE), Switzerland (CH), Turkey (TR), United Kingdom (UK).

\section{Appendix no. 2. Distribution of financial development (FIN_DEV)}

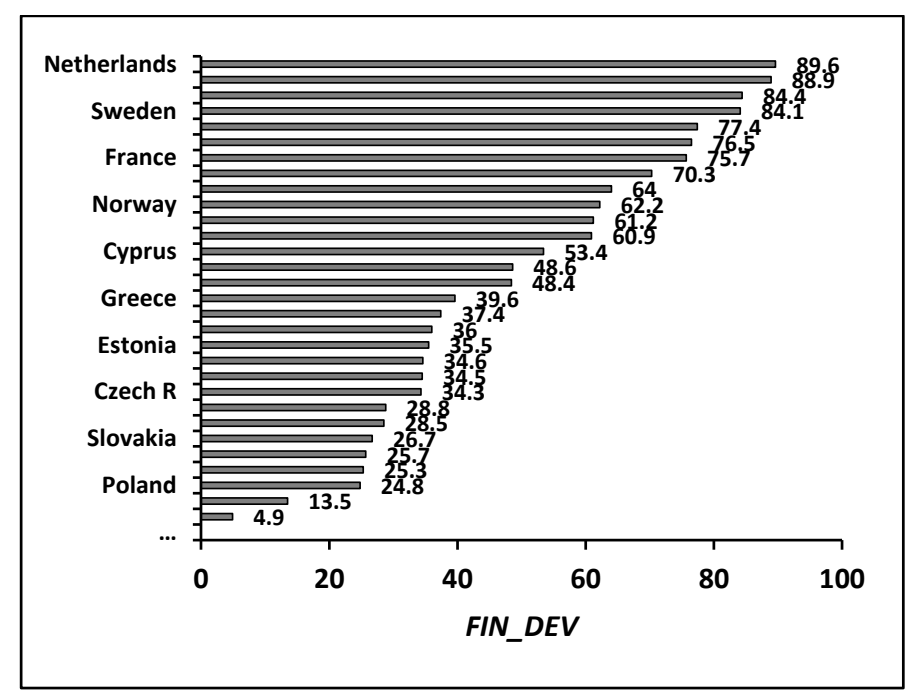

Source: authors' calculation in Excel. 